\title{
Synthesis, DNA-binding, Photocleavage and in vitro Cytotoxicity of Novel Imidazole[4,5-f][1,10]phenanthroline-based Oxovanadium Complexes
}

\author{
Peng Ying1, Xuyan Tian², Pengfei Zeng1, Jiazheng Lu*, Hongyuan Chen ${ }^{2 *}$ and Manshan Xiao² \\ ${ }^{1}$ Department of Chemistry, School of Pharmacy, Guangdong Pharmaceutical University, Guangzhou, 510006, P.R. China \\ ${ }^{2}$ Department of Pathogen Biology and Immunology, School of Basic Course, Guangdong Pharmaceutical University, Guangzhou 510060, P.R. China
}

\begin{abstract}
Three novel imidazole[4,5-f][1,10]phenanthroline-based oxovanadium complexes [VO(hntdtsc)(HPIP)] (1) (hntdtsc = 2-hydroxyl-1-naphthaldehyde thiosemicarbazone, HPIP = 2-(2-hydroxylphenyl)imidazole[4,5-f][1,10]phenanthroline), [VO(hntdtsc)(m-HPIP)] (2) (m-HPIP = 2-(3-hydroxylphenyl)imidazole[4,5-f][1,10]phenanthroline), [VO(hntdtsc)(p-HPIP) (3) ( $\mathrm{p}$-HPIP = 2-(4-hydroxylphenyl)imidazole[4,5-f][1,10]phenanthroline), have been synthesized and characterized by elemental analyses and spectroscopic techniques. Their DNA-binding properties with calf-thymus DNA (CT-DNA) were studied by various methods. The cytotoxicity of these three complexes was evaluated by 3-(4,5-dimethylthiazol2-yl)-2,5-diphenyltetrazolium bromide (MTT) assay. The electronic spectral results reveal that three complexes can bind to CT-DNA by intercalation mode. The electrophoresis studies also show that they can efficiently cleave pBR322 DNA. The in vitro antiproliferative activity of complex 1 against human CaSki, SiHa, K562, HepG2, EC9706 and EC109 cell lines is proved to be more effective than both 2 and 3 .
\end{abstract}

Keywords: Oxovanadium complexes; DNA-binding; Photocleavage; Cytotoxicity

\section{Introduction}

In recent years, more and more biochemists and pharmacologists have paid their attention to research on other transition metal complexes such as ruthenium (II), copper (II), zinc (II), nickel (II), cobalt (II) complexes compared with traditional platinum compounds in treatment of human cancer due to their potential applications as chemical and stereoselective probes of nucleic acid structures as well as diverse biological activities [1-5]. As a trace bioelement existing in the human body, vanadium has been found to present a variety of physiological activities such as nutritional metabolism [6], insulin mimetic effect [7], as well as closely connected with cell apoptosis and cancer [8]. In the past decades, oxovanadium compounds have been extensively studied for their potential biological and pharmacological activities such as antibacterial [9], biocatalytic oxidation [10], insulinenhancing effects [11], apoptosis-inducing activity [12], potential capabilities as DNA structural probes and DNA dependent electron transfer likewise [13].

In addition, thiosemicarbazones were often chosen as primary ligands for vanadium owing to their wide range of physiological and pharmacological activities including antifungal [14], antitumor [15], antibacterial [16] and antiviral activities [17]. Oxovanadium complexes incorporated with thiosemicarbazones have demonstrated both in vitro antibacterial and antiproliferative properties [18-19] as well as intense interaction with DNA [20]. On the other hand, 1,10-phenanthroline and its derivatives were usually served as a very efficient class of ligands, which lead to efficient catalysis in cross coupling reaction of aliphatic alcohols and aryl halides [21], antimicrobial activities [22], efficient DNA-binding and DNA cleavage [23] thus inducing significant cytotoxicity in the cultured cells [24]. Subsequently, research on mixedligand metal complexes has been put into practice in order to combine the pharmacological properties of both the ligands and metal thus reduce toxicity simultaneously [25]. So far, a certain attentions have been paid to $\mathrm{Ru}$ (II), $\mathrm{Cu}$ (II), $\mathrm{Co}$ (II) and $\mathrm{Ni}$ (II) complexes incorporating imidazole[4,5-f][1,10]phenanthroline derivatives ligands [26-27]. However, there have been relatively few studies on oxovanadium complexes with imidazole derivatives of 1,10-phenanthroline and their mechanism.

Previously, we have reported some oxovanadium (IV) complexes incorporating 1,10-phenanthroline (phen) or bipyridyl (bpy) present high DNA intercalator, photocleavage properties and cytotoxicity in vitro [13,19-20]. Although the molecular basis for the DNAbinding properties of oxovanadium (IV) compound is not completely understood at the present time, it occurs to us that oxovanadium complexes bearing phen moiety possess higher DNA-binding activities and more potent inhibitory effect against cancer cell lines than that of bearing bpy moiety. The previous results provide strong evidence for us to assume that DNA-binding activity of oxovanadium complexes may increase owing to the introduction of larger aromatic ring in auxiliary ligands substituted with 1, 10-phenanthroline.

In the present work, we have synthesized three unsymmetrical imidazole $[4,5-\mathrm{f}][1,10]$ phenanthroline-based oxovanadium complexes [VO(hntdtsc)(HPIP)] (1) (hntdtsc = 2-hydroxyl-1-naphthaldehyde thiosemicarbazone, HPIP = 2-(2-hydroxylphenyl)imidazole $[4,5-\mathrm{f}][1,10]$ phenanthroline), [VO(hntdtsc)(m-HPIP)] (2) (m-HPIP = 2-(3-hydroxylphenyl)imidazole[4,5-f][1,10]phenanthroline), [VO(hntdtsc) (p-HPIP) (3) (p-HPIP = 2-(4-hydroxylphenyl)imidazole $[4,5-\mathrm{f}][1,10]$ phenanthroline), and characterized by elemental analysis, IR, molar conductance, ES-MS and ${ }^{1} \mathrm{H}$ NMR. The DNA-binding properties of these three complexes were well studied by UV-Vis titration, fluorescence spectra, viscosity measurements and thermal denaturation studies. Photocleavage rections with pBR322 supercolied plasmid DNA were investigated by agarose gel electrophoresis experiments. Their cytotoxicity in vitro against cervical cancer CaSki and SiHa, leukemia K562, HepG2, esophagus carcinoma EC9706 and EC109 cell lines were

*Corresponding authors: Jiazheng Lu, Department of Chemistry, School of Pharmacy, Guangdong Pharmaceutical University, Guangzhou, 510006, P.R. China, Tel: +86-20-39352122; Fax: +86-20-39352129; E-mail: lujia6812@163.com

Hongyuan Chen, Department of Pathogen Biology and Immunology, School of Basic Course, Guangdong Pharmaceutical University, Guangzhou 510060, P.R. China, Tel: 86-020-3935219; E-mail: hychen1208@126.com

Received June 28, 2014; Accepted July 28, 2014; Published July 31, 2014

Citation: Ying P, Tian X, Zeng P, Lu J, Chen H, et al. (2014) Synthesis, DNAbinding, Photocleavage and in vitro Cytotoxicity of Novel Imidazole[4,5[1,10]phenanthroline-based Oxovanadium Complexes. Med chem 4: 549-557. doi:10.4172/2161-0444.1000193

Copyright: (c) 2014 Ying P, et al. This is an open-access article distributed under the terms of the Creative Commons Attribution License, which permits unrestricted use, distribution, and reproduction in any medium, provided the original author and source are credited. 
assessed by MTT assay. The compounds employed in this work are shown in Scheme 1.

\section{Experimental}

\section{Materials and methods}

All starting chemicals used in the synthesis and physical measurements were commercially available reagents and without further purification unless otherwise specified. 1,10-phenanthroline (phen) was obtained from Guangzhou Chemical Reagent Factory. VO(acac), were purchased from Alfa Aesar, thiosemicarbazide (TSC) was purchased from TCI, CT-DNA and pBR322 supercoiled plasmid DNA were obtained from Sigma. Cell lines of CaSki, SiHa, K562, HepG2, EC9706 and EC109 were purchased from American Type Culture Collection. Tris buffer A (Tris=tris(hydroxylmethyl) aminomethane ) containing $5 \mathrm{mM}$ Tris- $\mathrm{HCl}$ and $50 \mathrm{mM} \mathrm{NaCl}$ $(\mathrm{pH}=7.2)$ was used for absoption titration and viscosity measurements. Tris buffer $\mathrm{B}$ containing $50 \mathrm{mM}$ Tris- $\mathrm{HCl}$ and $18 \mathrm{mM} \mathrm{NaCl}(\mathrm{pH}=7.2)$ was used for the gel electrophoresis experiments. Buffer $\mathrm{C}$ containing $1.5 \mathrm{mM}$ $\mathrm{Na}_{2} \mathrm{HPO}_{4}, 0.5 \mathrm{mM} \mathrm{NaH}_{2} \mathrm{PO}_{4}$ and $0.25 \mathrm{mM} \mathrm{Na}_{2} \mathrm{H}_{2}$ EDTA $\left(\mathrm{H}_{4} \mathrm{EDTA}=\mathrm{N}, \mathrm{N}^{\prime}-\right.$ ethane-1,2-diylbis[N-(carboxymethyl) glycine]) ( $\mathrm{pH}=7.0)$ was used for thermal denaturation. A solution of CT-DNA in buffer A gave a ratio of UV absorbance at 260 and $280 \mathrm{~nm}$ of 1.8-1.9:1, indicating that the DNA was sufficiently free of protein [13,19]. The DNA concentration per nucleotide was determined by absorption spectroscopy using the molar absorption coefficient $\left(6600 \mathrm{M}^{-1} \mathrm{~cm}^{-1}\right)$ at $260 \mathrm{~nm}$ [20]. The oxovanadium complexes were dissolved in DMSO and diluted with buffer solution to the required concentrations prior to use. 2-hydroxyl-1-naphthaldehyde thiosemicarbazone (hntdtsc) was prepared according to a previously reported procedure [28].

\section{Physical measurements}

Microanalysis (C, H, and N) was carried out with a PerkinElmer 240Q elemental analyzer. Electrospray mass spectra (ES-MS) were recorded on an LCQ system (Finnigan MAT, USA) using methanol as mobile phase. ${ }^{1} \mathrm{H}$ NMR spectra were recorded on a Varian-500 spectrometer. All chemical shifts are given relative to tetramethylsilane (TMS). Infrared spectra were recorded on a Bomem FTIR model MB102 instrument using $\mathrm{KBr}$ pellets method. UV-Vis spectra were recorded on a Shimadzu UV-3101 PC spectrophotometer at room temperature. Emission spectra were recorded on a Perkin-Elmer Lambda 55 spectrofluorophotometer. Molar conductivities in DMF $\left(10^{-3} \mathrm{M}\right)$ solution at room temperature were measured using a DDS-307 digital direct reading conductivity meter.

\section{Synthesis of phenanthroline-based ligands: HPIP, m-HPIP and p-HPIP}

HPIP was synthesized through modification of a previously reported method [29]. A mixture of salicylaldehyde $(0.69 \mathrm{~mL}, 5$ $\mathrm{mmol})$ and ammonium acetate $(7.70 \mathrm{~g}, 0.1 \mathrm{~mol})$ was added into a stirring solution of 1, 10-phenanthroline-5, 6-dione ( $0.99 \mathrm{~g}, 5 \mathrm{mmol})$ in $60 \mathrm{~mL}$ of glacial acetic acid, and the mixture was continuously stirred at $60^{\circ} \mathrm{C}$ for 6 hours. Then the deep red solution was cooled to room temperature and diluted with $100 \mathrm{~mL}$ distilled water. A grayish precipitate was obtained by neutralization with ammonium hydroxide. Then the mixture was filtered and washed with water for three times. The crude solid power was purified by chromatography over $60-80$ mesh $\mathrm{SiO}_{2}$ using absolute ethanol as eluent. The solvent was removed and the products were collected, and dried in vacuo. $m$-HPIP and $p$-HPIP were prepared by a similar procedure as for the compound HPIP, with 3-Hydroxybenzaldehyde $(0.69 \mathrm{~mL}, 5 \mathrm{mmol})$ and 4-Hydroxybenzaldehyde $(0.69 \mathrm{~mL}, 5 \mathrm{mmol})$ in place of salicylaldehyde $(0.69 \mathrm{~mL}, 5 \mathrm{mmol})$ respectively, and a grey-white precipitate were obtained.

HPIP: Yield: 86\%. Anal. Found: C, 73.12; H, 3.79; N, 18.03; Calcd for $\mathrm{C}_{19} \mathrm{H}_{12} \mathrm{~N}_{4} \mathrm{O}: \mathrm{C}, 73.07 ; \mathrm{H}, 3.87 ; \mathrm{N}, 17.94 .{ }^{1} \mathrm{H}$ NMR (DMSO-d $\mathrm{d}_{6}, 500$ $\mathrm{MHz}) \delta: 12.85(\mathrm{~s}, 1 \mathrm{H},-\mathrm{NH}), 10.07(\mathrm{~s}, 1 \mathrm{H},-\mathrm{OH}), 9.91(\mathrm{~d}, 2 \mathrm{H}, J=7.4 \mathrm{~Hz}$ ArH), 9.85 (d, $2 \mathrm{H}, J=8.0 \mathrm{~Hz}, \mathrm{ArH}), 9.28(\mathrm{~d}, 1 \mathrm{H}, J=7.7 \mathrm{~Hz}, \mathrm{ArH}), 8.75$ -<smiles>NC(=S)N/N=C/c1c(O)ccc2ccccc12</smiles><smiles>[R]c1cc([R])c(-c2nc3c4cccnc4c4ncccc4c3[nH]2)cc1[R]</smiles>

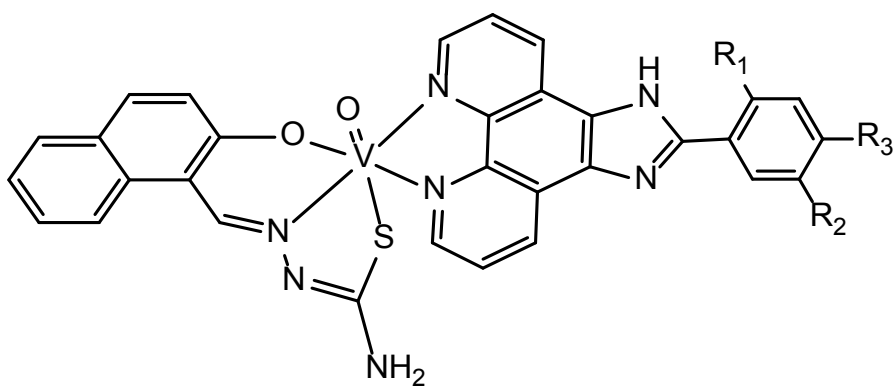

Scheme 1: Synthesis of $V O(h n t d t s c)(H P I P)(1), R_{1}=O H, R_{2}=H, R_{3}=H$; VO(hntdtsc)(m-HPIP) (2), $R_{1}=H, R_{2}=O H, R_{3}=H ;$ VO(hntdtsc)(p-HPIP) (3), $R_{1}=H, R_{2}=H, R_{3}=O H$. 
$8.68(\mathrm{~m}, 2 \mathrm{H}, J=8.1 \mathrm{~Hz}, \mathrm{ArH}), 8.23(\mathrm{t}, J=7.6 \mathrm{~Hz}, 1 \mathrm{H}, \mathrm{ArH}), 7.99-7.90$ $(\mathrm{m}, 2 \mathrm{H}, J=8.3 \mathrm{~Hz}, \mathrm{ArH}) .{ }^{13} \mathrm{C}$ NMR (DMSO-d, $\left.500 \mathrm{MHz}\right) \delta: 157.5 \mathrm{C}\left(2^{\prime}\right)$, 146.4 C(13), $142.9 \mathrm{C}(1,10), 129.6 \mathrm{C}(5,6), 128.6 \mathrm{C}(4,7), 126.2 \mathrm{C}(3,8)$, $122.9 \mathrm{C}\left(4^{\prime}, 6^{\prime}\right), 122.5 \mathrm{C}(4,12), 120.8 \mathrm{C}\left(5^{\prime}\right), 118.4 \mathrm{C}(2,9), 116.6 \mathrm{C}\left(1^{\prime}\right)$, $116.3 \mathrm{C}\left(3^{\prime}\right)$. ES-MS: $\left(\mathrm{CH}_{3} \mathrm{OH}\right): \mathrm{m} / \mathrm{z} 313.0\left([\mathrm{M}+\mathrm{H}]^{+}\right)$. IR (KBr disk): $v\left(\mathrm{~cm}^{-1}\right)=3383.0\left(\mathrm{~s}, v_{\mathrm{O}-\mathrm{H}}\right), 3255.6(\mathrm{~s}), 3264.3(\mathrm{~s},-\mathrm{NH} 2), 3186.8\left(\mathrm{~s}, v_{\mathrm{N}-}\right.$ $\left.{ }_{\mathrm{H}}\right), 3036.8\left(\mathrm{~m}, v_{\mathrm{C}-\mathrm{H}}\right), 1608.5(\mathrm{~s}), 1566.0(\mathrm{~s}), 1486.8\left(\mathrm{vs}, \mathrm{v}_{\mathrm{C}=\mathrm{C}}\right), 738.0(\mathrm{vs})$, $699.1\left(\mathrm{~s}, \delta_{\mathrm{C}-\mathrm{H}}\right)$. Conductance $\left(\Omega^{-1} \mathrm{~cm}^{2} \mathrm{~mol}^{-1}\right): 8.6$.

m-HPIP: Yield: 79\%. Anal. Found: C, 73.02; H, 3.67; N, 18.04; Calcd for $\mathrm{C}_{19} \mathrm{H}_{12} \mathrm{~N}_{4} \mathrm{O}$ : C, 73.07; H, 3.87; N, 17.94. ${ }^{1} \mathrm{H}$ NMR (DMSO-d, $500 \mathrm{MHz}) \delta: 13.52(\mathrm{~s}, 1 \mathrm{H},-\mathrm{NH}), 10.04(\mathrm{~s}, 1 \mathrm{H},-\mathrm{OH}), 9.01$ (d, 2H, $J=$ $7.2 \mathrm{~Hz}, \mathrm{ArH}), 8.90(\mathrm{dd}, 2 \mathrm{H}, J=8.1 \mathrm{~Hz}, 1.5 \mathrm{~Hz}, \mathrm{ArH}), 8.73(\mathrm{~d}, 1 \mathrm{H}, J=$ $8.8 \mathrm{~Hz}, \mathrm{ArH}), 8.12(\mathrm{~d}, 2 \mathrm{H}, J=8.6 \mathrm{~Hz}, \mathrm{ArH}), 7.82(\mathrm{~s}, 1 \mathrm{H}, \mathrm{ArH}), 6.99-6.98$ $(\mathrm{d}, 2 \mathrm{H}, J=8.6 \mathrm{~Hz}, \mathrm{ArH}) .{ }^{13} \mathrm{C}$ NMR (DMSO-d 6 , $\left.500 \mathrm{MHz}\right) \delta: 158.9 \mathrm{C}\left(2^{\prime}\right)$, 151.2 C(13), 147.4 C (1, 10), 129.3 C (5, 6), $127.9 \mathrm{C}(4,7), 123.0 \mathrm{C}(3,8)$, $122.6 \mathrm{C}\left(4^{\prime}, 6^{\prime}\right), 122.1 \mathrm{C}(4,12), 120.5 \mathrm{C}\left(5^{\prime}\right), 118.8 \mathrm{C}(2,9), 116.7 \mathrm{C}\left(1^{\prime}\right)$, $115.8 \mathrm{C}\left(3^{\prime}\right)$. ES-MS: $\left(\mathrm{CH}_{3} \mathrm{OH}\right): \mathrm{m} / \mathrm{z} 313.0\left([\mathrm{M}+\mathrm{H}]^{+}\right)$. IR (KBr disk): $v\left(\mathrm{~cm}^{-1}\right)=3383.6\left(\mathrm{~s}, v_{\mathrm{O}-\mathrm{H}}\right), 3263.0(\mathrm{~s}), 3256.5(\mathrm{~s},-\mathrm{NH} 2), 3187.0\left(\mathrm{~s}, v_{\mathrm{N}-}\right.$ $\left.{ }_{\mathrm{H}}\right), 3046.2\left(\mathrm{~m}, v_{\mathrm{C}-\mathrm{H}}\right), 1604.5(\mathrm{~s}), 1565.6(\mathrm{~s}), 1486.6\left(\mathrm{vs}, \mathrm{v}_{\mathrm{C}=\mathrm{C}}\right), 738.5(\mathrm{vs})$, $696.3\left(\mathrm{~s}, \delta_{\mathrm{C}-\mathrm{H}}\right)$. Conductance $\left(\Omega^{-1} \mathrm{~cm}^{2} \mathrm{~mol}^{-1}\right)$ : 9.8 .

p-HPIP: Yield: 88\%. Anal. Found: C, 72.98; H, 3.94; N, 18.07; Calcd for $\mathrm{C}_{19} \mathrm{H}_{12} \mathrm{~N}_{4} \mathrm{O}$ : C, 73.07; H, 3.87; N, 17.94. ${ }^{1} \mathrm{H}$ NMR (DMSO-d 6 , 500 $\mathrm{MHz}) \delta: 13.08(\mathrm{~s}, 1 \mathrm{H},-\mathrm{NH}), 10.09(\mathrm{~s}, 1 \mathrm{H},-\mathrm{OH}), 8.96(\mathrm{~d}, 2 \mathrm{H}, J=7.9 \mathrm{~Hz}$, $\operatorname{ArH}), 8.84(\mathrm{~m}, 2 \mathrm{H}, J=8.0 \mathrm{~Hz}, \mathrm{ArH}), 8.43(\mathrm{~d}, 1 \mathrm{H}, J=8.2 \mathrm{~Hz}, \mathrm{ArH}), 7.77$ $(\mathrm{m}, 2 \mathrm{H}, J=7.6 \mathrm{~Hz}, \mathrm{ArH}), 7.33(\mathrm{~s}, 1 \mathrm{H}, \mathrm{ArH}), 6.93(\mathrm{~d}, 2 \mathrm{H}, J=8.0 \mathrm{~Hz}, \mathrm{ArH})$. ${ }^{13} \mathrm{C}$ NMR (DMSO-d, $\left.500 \mathrm{MHz}\right) \delta: 158.5 \mathrm{C}(2 '), 151.4 \mathrm{C}(13), 147.5 \mathrm{C}(1$, 10), $131.5 \mathrm{C}(5,6), 130.9 \mathrm{C}(4,7), 130.0 \mathrm{C}(3,8), 123.4 \mathrm{C}\left(4^{\prime}, 6^{\prime}\right), 121.8$ $\mathrm{C}(4,12), 120.9 \mathrm{C}\left(5^{\prime}\right), 119.5 \mathrm{C}(2,9), 116.9 \mathrm{C}\left(1^{\prime}\right), 113.5 \mathrm{C}\left(3^{\prime}\right)$. ES-MS: $\left(\mathrm{CH}_{3} \mathrm{OH}\right): \mathrm{m} / \mathrm{z} 313.0\left([\mathrm{M}+\mathrm{H}]^{+}\right)$. IR $(\mathrm{KBr}$ disk $): v\left(\mathrm{~cm}^{-1}\right)=3498.9\left(\mathrm{~s}, v_{\mathrm{O}}\right.$ $\left.{ }_{\mathrm{H}}\right), 3248.9(\mathrm{~s}), 3217.7\left(\mathrm{~s},-\mathrm{NH}_{2}\right), 3189.5\left(\mathrm{~s}, v_{\mathrm{N}-\mathrm{H})} 3034.9\left(\mathrm{~m}, v_{\mathrm{C}-\mathrm{H}}\right), 1618.2\right.$ $(\mathrm{s}), 1578.4(\mathrm{~s}), 1448.4\left(\mathrm{vs}, v_{\mathrm{C}=\mathrm{C}}\right), 742.2(\mathrm{vs}), 700.9\left(\mathrm{~s}, \delta_{\mathrm{C}-\mathrm{H}}\right)$. Conductance $\left(\Omega^{-1} \mathrm{~cm}^{2} \mathrm{~mol}^{-1}\right): 11.4$.

\section{Synthesis of [VO(hntdtsc)(HPIP)] (1)}

This complex was synthesized by a mixture of HPIP $(0.312 \mathrm{~g}, 1$ mmol) and hntdtsc $(0.245 \mathrm{~g}, 1 \mathrm{mmol})$ in absolute $\mathrm{CH}_{3} \mathrm{OH}(60 \mathrm{~mL})$ was heated at $80^{\circ} \mathrm{C}$ under argon for $2 \mathrm{~h}$. After dissolution, an aqueous solution $(10 \mathrm{~mL})$ of $1.0 \mathrm{mmol}(0.265 \mathrm{~g})$ quantity of $\mathrm{VO}(\mathrm{acac})_{2}$, was added dropwise to this mixture, and a breen precipitate was formed. The soild power was purified by recrystallization in methanol, and dried in vacuo. Yield: $76 \%$. Anal. Found: C, 60.08; H, 3.42; N, 15.69; Calcd for $\mathrm{C}_{31} \mathrm{H}_{21} \mathrm{~N}_{7} \mathrm{O}_{3} \mathrm{SV}$ : C, 59.81; H, 3.40; N, 15.75. ${ }^{1} \mathrm{H}-\mathrm{NMR}$ (DMSO-d $\mathrm{d}_{6}$, $500 \mathrm{MHz}) \delta: 12.65(\mathrm{~s}, 1 \mathrm{H},-\mathrm{NH}), 11.40(\mathrm{~s}, 1 \mathrm{H}, \mathrm{CH}=\mathrm{N}), 10.49(\mathrm{~s}, 1 \mathrm{H}$, -OH), 9.05 (d, $2 \mathrm{H}, J=8.5 \mathrm{~Hz}, \mathrm{ArH}), 8.42(\mathrm{~d}, 2 \mathrm{H}, J=8.4 \mathrm{~Hz}, \mathrm{ArH}), 8.18$ and $7.84\left(2 \mathrm{br} \mathrm{s}, 1 \mathrm{H}\right.$ each $\left.\mathrm{NH}_{2}\right), 8.12(\mathrm{~d}, 2 \mathrm{H}, J=8.1 \mathrm{~Hz}, \mathrm{ArH}), 7.64(\mathrm{~d}$, $2 \mathrm{H}, \mathrm{ArH}), 7.34-7.55(\mathrm{~m}, 4 \mathrm{H}, J=7.8 \mathrm{~Hz}, \mathrm{ArH}), 7.11-7.24(\mathrm{~m}, 4 \mathrm{H}, J=8.5$ $\mathrm{Hz}, \mathrm{ArH})$. ES-MS $\left(\mathrm{CH}_{3} \mathrm{OH}\right): \mathrm{m} / \mathrm{z}: 623.0\left([\mathrm{M}+\mathrm{H}]^{+}\right), 645.0\left([\mathrm{M}+\mathrm{Na}]^{+}\right)$. IR (KBr disk): $v\left(\mathrm{~cm}^{-1}\right)=3447.2\left(v_{\mathrm{O}-\mathrm{H}}\right), 3338.4(\mathrm{~s}), 3275.1\left(\mathrm{~s},-\mathrm{NH}_{2}\right)$, $3031.9(\mathrm{~m}), 1573.2(\mathrm{~s}), 1493.8\left(\mathrm{~s}, \mathrm{v}_{\mathrm{C}=\mathrm{C}-\mathrm{H}}\right), 1612.9\left(\mathrm{vs}, \mathrm{v}_{\mathrm{HC}=\mathrm{N}}\right), 1193.7(\mathrm{~m}$, $\left.v_{\mathrm{C}-\mathrm{O}}\right), 1086.1\left(\mathrm{~m}, v_{\mathrm{C}-\mathrm{N}}\right), 952.0\left(\mathrm{~s}, v_{\mathrm{V}=\mathrm{O}}\right), 821.8(\mathrm{~s}), 755.9\left(\mathrm{~m}, v_{\mathrm{C}-\mathrm{S}}\right), 731.9$ $\left(\mathrm{m}, v_{\mathrm{v}-\mathrm{N}}\right)$. Conductance $\left(\Omega^{-1} \mathrm{~cm}^{2} \mathrm{~mol}^{-1}\right): 13.6$.

\section{Synthesis of [VO(hntdtsc)(m-HPIP)] (2)}

This complex was obtained by a similar procedure as for the complex 1, with m-HPIP $(0.312 \mathrm{~g}, 1 \mathrm{mmol})$ in place of HPIP. Yield: $72 \%$. Anal. Found: C, 60.02; H, 3.39; N, 15.79; Calcd for $\mathrm{C}_{31} \mathrm{H}_{21} \mathrm{~N}_{7} \mathrm{O}_{3} \mathrm{SV}$ : C, 59.81; H, 3.40; N, 15.75. ${ }^{1} \mathrm{H}-\mathrm{NMR}$ (DMSO-d, $\left.500 \mathrm{MHz}\right) \delta: 14.31(\mathrm{~s}$, $1 \mathrm{H},-\mathrm{NH}), 10.18(\mathrm{~s}, 1 \mathrm{H}, \mathrm{CH}=\mathrm{N}), 9.41(\mathrm{~s}, 1 \mathrm{H},-\mathrm{OH}), 9.21(\mathrm{~d}, 2 \mathrm{H}, J=8.5$ $\mathrm{Hz}, \mathrm{ArH}), 8.13(\mathrm{~m}, 4 \mathrm{H}, J=8.4 \mathrm{~Hz}, \mathrm{ArH}), 8.11$ and 7.84 (2br s, $1 \mathrm{H}$ each $\left.\mathrm{NH}_{2}\right), 7.50(\mathrm{~m}, 4 \mathrm{H}, J=8.1 \mathrm{~Hz}, \mathrm{ArH}), 7.33(\mathrm{~d}, 2 \mathrm{H}, J=8.1 \mathrm{~Hz}, \mathrm{ArH}), 7.00$ $(\mathrm{t}, 4 \mathrm{H}, J=7.9 \mathrm{~Hz}, \mathrm{ArH})$. ES-MS $\left(\mathrm{CH}_{3} \mathrm{OH}\right): \mathrm{m} / \mathrm{z}: 623.0\left([\mathrm{M}+\mathrm{H}]^{+}\right), 645.0$
$\left([\mathrm{M}+\mathrm{Na}]^{+}\right)$. IR $(\mathrm{KBr}$ disk $): v\left(\mathrm{~cm}^{-1}\right)=3444.7\left(v_{\mathrm{O}-\mathrm{H}}\right), 3341.1(\mathrm{~s}), 3200.2$ $\left(\mathrm{s},-\mathrm{NH}_{2}\right), 3021.9(\mathrm{~m}), 1597.1(\mathrm{~s}), 1538.1(\mathrm{~s}), 1491.4\left(\mathrm{~s}, v_{\mathrm{C}=\mathrm{C}-\mathrm{H}}\right), 1614.3$ $\left(\mathrm{vs}, v_{\mathrm{HC}=\mathrm{N}}\right), 1195.3\left(\mathrm{~m}, v_{\mathrm{C}-\mathrm{O}}\right), 1083.3\left(\mathrm{~m}, v_{\mathrm{C}-\mathrm{N}}\right), 955.5\left(\mathrm{~s}, v_{\mathrm{V}=\mathrm{O}}\right), 825.7(\mathrm{~s})$, $813.2\left(\mathrm{~m}, v_{\mathrm{C}-\mathrm{S}}\right), 737.6\left(\mathrm{~m}, v_{\mathrm{V}-\mathrm{N}}\right)$. Conductance $\left(\Omega^{-1} \mathrm{~cm}^{2} \mathrm{~mol}^{-1}\right): 12.8$.

\section{Synthesis of [VO(hntdtsc)(p-HPIP)] (3)}

This compound was synthesized by a similar procedure as for the complex 1, with p-HPIP (0.312 g, $1 \mathrm{mmol})$ in place of HPIP. Yield: 69\%. Anal. Found: C, 59.68; H, 3.32; N, 15.77; Calcd for $\mathrm{C}_{31} \mathrm{H}_{21} \mathrm{~N}_{7} \mathrm{O}_{3} \mathrm{SV}$ : C, 59.81; H, 3.40; N, 15.75. ${ }^{1} \mathrm{H}-\mathrm{NMR}\left(\mathrm{DMSO}-\mathrm{d}_{6}, 500 \mathrm{MHz}\right) \delta: 13.73$ (s, $1 \mathrm{H},-\mathrm{NH}), 12.40(\mathrm{~s}, 1 \mathrm{H}, \mathrm{CH}=\mathrm{N}), 9.85(\mathrm{~s}, 1 \mathrm{H},-\mathrm{OH}), 9.00(\mathrm{~d}, 2 \mathrm{H}, J=8.6$ $\mathrm{Hz}, \mathrm{ArH}), 8.84(\mathrm{~d}, 2 \mathrm{H}, J=7.9 \mathrm{~Hz}, \mathrm{ArH}), 8.02$ and 7.79 (2br s, $1 \mathrm{H}$ each $\left.\mathrm{NH}_{2}\right), 7.57(\mathrm{~m}, 4 \mathrm{H}, J=8.2 \mathrm{~Hz}, \mathrm{ArH}), 7.29(\mathrm{t}, 4 \mathrm{H}, \mathrm{J}=8.2 \mathrm{~Hz}, \mathrm{ArH}), 7.08$ $6.86(\mathrm{~m}, 4 \mathrm{H}, J=8.3 \mathrm{~Hz}, \mathrm{ArH})$. ES-MS $\left(\mathrm{CH}_{3} \mathrm{OH}\right): \mathrm{m} / \mathrm{z}: 623.0\left([\mathrm{M}+\mathrm{H}]^{+}\right)$, $645.0\left([\mathrm{M}+\mathrm{Na}]^{+}\right)$. IR $(\mathrm{KBr}$ disk $): v\left(\mathrm{~cm}^{-1}\right)=3441.2\left(v_{\mathrm{O}-\mathrm{H}}\right), 3333.0(\mathrm{~s})$, $3181.8\left(\mathrm{~s},-\mathrm{NH}_{2}\right), 3034.8(\mathrm{~m}), 1576.7(\mathrm{~s}), 1538.8(\mathrm{~s}), 1507.6\left(\mathrm{~s}, v_{\mathrm{C}=\mathrm{C}-\mathrm{H}}\right)$, $1616.1\left(\mathrm{vs}, v_{\mathrm{HC}=\mathrm{N}}\right), 1168.3\left(\mathrm{~m}, v_{\mathrm{C}-\mathrm{O}}\right), 1079.0\left(\mathrm{~m}, v_{\mathrm{C}-\mathrm{N}}\right), 965.1\left(\mathrm{~s}, v_{\mathrm{V}=\mathrm{O}}\right)$, $825.7(\mathrm{~s}), 812.1\left(\mathrm{~m}, v_{\mathrm{C}-\mathrm{S}}\right), 731.0\left(\mathrm{~m}, v_{\mathrm{V}-\mathrm{N}}\right)$. Conductance $\left(\Omega^{-1} \mathrm{~cm}^{2} \mathrm{~mol}^{-1}\right)$ : 18.1 .

\section{DNA-binding and photocleavage}

The absorption titration of oxovanadium complexes in buffer $\mathrm{A}$ were performed at room temperature with a fixed concentration of the oxovanadium complex $(20 \mathrm{mM})$ to which increments of DNA stock solutions were added. The oxovanadium-DNA solutions were incubated at room temperature for $5 \mathrm{~min}$ before the absorption spectra were recorded. In order to further elucidate the binding strength of the complex, the intrinsic binding constant $K_{b}$ with CT-DNA was obtained by monitoring the change in the absorbance of the ligand transfer band with increasing amounts of DNA. $K_{b}$ was then calculated using the following equation $[13,20,28]$

$$
\frac{[D N A]}{\varepsilon_{a}-\varepsilon_{f}}=\frac{[D N A]}{\varepsilon_{b}-\varepsilon_{f}}+\frac{1}{K_{b}\left(\varepsilon_{b}-\varepsilon_{f}\right)}
$$

Where [DNA] is the concentration of DNA in the base pairs, and $\varepsilon_{\mathrm{a}}, \varepsilon_{\mathrm{f}}$ and $\varepsilon_{\mathrm{b}}$ refer to the corresponding apparent absorption coefficient $\mathrm{A}_{\text {obsd }} /[$ Vanadium], the extinction coefficient for the free oxovanadium complex and the extinction coefficient for the oxovanadium complex in the fully bound form, respectively. In plots of [DNA]/( $\left.\varepsilon_{\mathrm{a}}-\varepsilon_{\mathrm{f}}\right)$ versus [DNA], $K_{b}$ is obtained by the ratio of the slope to the intercept.

Viscosity measurements were carried out with an Ubbelohde viscometer maintained at a constant temperature of $(28.0 \pm 0.1){ }^{\circ} \mathrm{C}$ in a thermostatic bath. Flow time was measured with a digital stopwatch, and each sample was measured five times to obtain the average flow time. Date are presented as $\left(\eta / \eta_{0}\right)^{1 / 3}$ versus binding ratio [30], where $\eta$ is the viscosity of DNA in the presence of complex while $\eta_{0}$ is the viscosity of DNA alone.

Thermal denaturation studies were carried out with Shimadzu UV-3101 PC spectrophotometer equipped with a Peltier temperaturecontrolling programmer $\left( \pm 0.1^{\circ} \mathrm{C}\right)$. The melting temperature $\left(\mathrm{T}_{\mathrm{m}}\right)$ was taken as the mid-point of the hyperchromic transition. The melting curves were obtained by measuring the absorbance at 260 $\mathrm{nm}$ for solutions of CT-DNA $(80 \mu \mathrm{M})$ in the absence and presence of oxovanadium complex $[20 \mu \mathrm{M}]$ as a function of the temperature was scanned from 50 to $90^{\circ} \mathrm{C}$ at a speed of $5^{\circ} \mathrm{C} \mathrm{min}$. The data are presented as $\left(A-A_{0}\right) /\left(A_{f}-A_{0}\right)$ verus $T$, where $A, A_{0}$ and $A_{f}$ are the observed, the initial, and the final absorbance at $260 \mathrm{~nm}$, respectively.

The cleavage activity of supercoiled pBR322 DNA by the oxovanadium complexes was studied by using agarose gel electrophoresis experiment, pBR322 DNA $(0.1 \mu \mathrm{g})$ was treated with the 
complex in buffer $\mathrm{B}$ in different concentrations, and the solutions were incubated at $37^{\circ} \mathrm{C}$ in the incubator for $1 \mathrm{~h}$. The samples were analyzed by electrophoresis for $2 \mathrm{~h}$ at $90 \mathrm{~V}$ in tris-boric buffer containing $0.8 \%$ agarose gel. The gel was stained with $0.1 \mu \mathrm{g} / \mathrm{mL}$ DuRed nucleic acid gel stain and photographed under UV light on an Alpha Innotech IS-5500 fluorescence chemiluminescence and visible imaging system $[19,20,31]$.

\section{Cell viability assay}

3-(4,5-Dimethylthiazole)-2,5-diphenyltetrazolium bromide (MTT) dye assay was carried out to evaluate cytotoxicity in human CaSki, SiHa, K562, HepG2, EC9706 and EC109 cell lines. Cells were seeded in 96-well microassay culture plates $\left(2 \times 10^{4}\right.$ cells per well $)$ and incubated at $37^{\circ} \mathrm{C}$ in a $5 \% \mathrm{CO}_{2}$ atmosphere for $48 \mathrm{~h}$. The compounds tested were then added to the wells to achieve final concentration ranging $10^{-6}$ to $10^{-4} \mathrm{~mol} \mathrm{~L}^{-1}$. Control wells were prepared by addition of culture medium $(100 \mu \mathrm{L})$. Wells containing culture medium without cells were used as blanks. Upon completion of the incubation, then stock MTT dye solution $\left(20 \mu \mathrm{L}, 5 \mathrm{mg} \mathrm{mL}^{-1}\right)$ was added to each well. After $4 \mathrm{~h}$ incubation, a solution containing $\mathrm{N}, \mathrm{N}$-dimethylformanmide (50\%) and sodium dodecyl sulfate $(20 \%)$ was added to solubilize the MTT formazan. The cell viability of each well was then measured on a Multiskan SSCENT microplate reader at $490 \mathrm{~nm}$. The $\mathrm{IC}_{50}$ values were determined by plotting the percentage viability versus concentration on a logarithmic graph and reading off the concentration at which $50 \%$ of cells remain viable relative to the control [32]. Each experiment was repeated at least three times to get the mean values.

\section{Results and Discussion}

\section{Synthesis of ligands and V-complexes}

The phenanthroline-based derivatives ligands were prepared by the reaction of 1,10-phenanthroline-5,6-dione with hydroxybenzaldehyde in the appropriate mole ratios in the presence of ammonium acetate using glacial acetic acid as solvent. The oxovanadium complexes 1-3 were synthesized by refluxing of corresponding ligand, $\mathrm{VO}$ (acac) and phenanthroline-based ligand in absolute methanol. The desired complexes were purified by recrystallization.

In the IR spectra of phenanthroline-based ligands show absorption at ca. $3340 \mathrm{~cm}^{-1}\left(v_{\mathrm{O}-\mathrm{H}}\right), 3200 \mathrm{~cm}^{-1}$ (imidazole $\left.\mathrm{N}-\mathrm{H}\right), 3040 \mathrm{~cm}^{-1}\left(v_{\mathrm{C}=\mathrm{C}-\mathrm{H}}\right)$, $1448-1618 \mathrm{~cm}^{-1}\left(v_{\mathrm{C} C \mathrm{C}}\right), 740 \mathrm{~cm}^{-1}, 700 \mathrm{~cm}^{-1}\left(\delta_{\mathrm{C}-\mathrm{H}}\right)$, respectively. In parallel, IR spectra absorption of complexes 1-3 observed at ca. $3440 \mathrm{~cm}^{-1}\left(v_{\mathrm{O}}\right.$ $\left.{ }_{\mathrm{H}}\right), 3180 \mathrm{~cm}^{-1}$ and $3340 \mathrm{~cm}^{-1}$ is assigned to $\left(-\mathrm{NH}_{2}\right), 3030 \mathrm{~cm}^{-1}\left(v_{\mathrm{C}=\mathrm{C}-\mathrm{H}}\right)$, $1490-1580 \mathrm{~cm}^{-1}\left(v_{\mathrm{C}=\mathrm{C}}\right), 1612-1616 \mathrm{~cm}^{-1}\left(v_{-\mathrm{CH}=\mathrm{N}}\right), 1312 \mathrm{~cm}^{-1}, 810-313$ $\left(v_{\mathrm{C}-\mathrm{S}}\right), 731-737 \mathrm{~cm}^{-1}$ for $\left(v_{\mathrm{v}-\mathrm{N}}\right)$, which indicates both two mixed ligands are coordinated to vanadium. The strong $\left(v_{\mathrm{V}=\mathrm{O}}\right)$ band at $956-974 \mathrm{~cm}^{-1}$ observed at oxovanadium complexes, which is not present in the spectrum of free ligands could be cleared identified for the formulation of the complex [33-34].

Electronic spectra of complexes 1-3 show an intense band at ca. 268 $\mathrm{nm}$ assignable to $\pi-\pi^{*}$ transition of aromatic rings of phenanthrolinebased ligands [35-36] The remaining bands in the UV-vis region (320$330 \mathrm{~nm}$ ) are attributed to intraligand transitions of the Schiff base. The obtained spectral data indicates the Schiff base bonded through the phenolate oxygen, imine nitrogen and thiolate sulfur atoms leaving the thiomethyl as the pendant group. These values are close to the reported values for a square-pyramidal geometry $[19,28,37]$ and it also suggested that these complexes bear the central V (IV) atom with coordination numbers 5 in a square-pyramidal geometry.

In the ${ }^{1} \mathrm{H}$ NMR spectra of phenanthroline-based ligands showed peaks of aromatic hydrogen $(\mathrm{ArH})$, imidazole secondary amine $(\mathrm{NH})$ proton. However, in the ${ }^{1} \mathrm{H}$ NMR spectra of complexes, the peaks of imine $(\mathrm{CH}=\mathrm{N})$ proton and primary amine $\left(-\mathrm{NH}_{2}\right)$ were observed, which affirmed that the Schiff base ligand was coordinated to vanadium.

According to the ES-MS spectra, the molecular ion peaks of three complexes appearing at $\mathrm{m} / \mathrm{z} 623.0\left([\mathrm{M}+\mathrm{H}]^{+}\right)$and $645.0\left([\mathrm{M}+\mathrm{Na}]^{+}\right)$. Elemental analysis, ES-MS, IR and ${ }^{1} \mathrm{H}$ NMR data of all the compounds are in good agreement with the expected structures.

The molar conductance values of phenanthroline-based ligands and complexes 1-3 in DMF (1 mM) are shown in Table 1. The conductive properties indicate that both oxovanadium complexes and the corresponding ligands are nonelectrolytes.

\section{Electronic absorption titration}

Electronic absorption spectral titration is one of the most common ways to investigate the interactions of compounds with DNA. To future evaluate the capacity of oxovanadium complexes interacting with CT-DNA, the electronic absorption spectra of complexes 1-3 are characterized by intense $\pi-\pi^{*}$ transition of aromatic rings in the absence and presence of increasing concertration of CT-DNA, which are shown in Figure 1. Complexes bind to the pairs base of DNA by $\pi-\pi^{*}$ stacking interactions between the planar aromatic chromophore of the complexes and the base pairs of DNA usually result in hypochromism and bathochromism $[13,20,28]$. As can be seen in Figure 1, with the CT-DNA concentration increasing, obvious hypochromism as well as a certain degree of bathochromism for the oxovanadium complex 1-3 can be observed in the ultraviolet titration process. The appreciable hypochromism and bathochromism for complex 1 is $56.17 \%$ and 3 $\mathrm{nm}$ at $272 \mathrm{~nm}$. In contrast, a slighter hypochromism can be observed for complexs 2 and 3, which exhibit $12.53 \%$ and $25.23 \%$, respectively, and also bathochromism of $1 \mathrm{~nm}$ at $268 \mathrm{~nm}$ and $1.5 \mathrm{~nm}$ at $270 \mathrm{~nm}$, respectively. According to previously reported results $[13,19,24]$, the UV-Vis spectral characteristics suggest that complexes 1-3 interact with CT-DNA most likely through a mode that involves a stacking interaction between the aromatic chromophore and the base pairs of DNA.

In order to compare quantitatively the DNA-binding strengths of these complexes, the intrinsic binding constant $K_{\mathrm{b}}$ was calculated from the changes in absorbance in the ligand change transfer bands with increasing amounts of CT-DNA. The value of $K_{\mathrm{b}}$ were calculated as well using the equation, reaching $(4.38 \pm 0.01) \times 10^{5} \mathrm{M}^{-1},(1.07 \pm$ $0.01) \times 10^{5} \mathrm{M}^{-1}$ and $(1.83 \pm 0.01) \times 10^{5} \mathrm{M}^{-1}$ for complexes 1,2 and 3 , respectively. The $K_{\mathrm{b}}$ values indicate that oxovanadium complexes 1-3 interact with CT-DNA by intercalation modes. It is interesting to note that the DNA-binding affinities of complexes 1,2 and 3 are stronger than that of the reported oxovanadium complexes, such as VO(SAA) (phen) $\left(4.50 \times 10^{4} \mathrm{M}^{-1}\right), \mathrm{VO}\left(\right.$ MOSAA)(phen) $\left(2.95 \times 10^{4} \mathrm{M}^{-1}\right)$ [19] and $\mathrm{VO}$ (hntdtsc)(phen) $\left(8.2 \times 10^{4} \mathrm{M}^{-1}\right)$ [28], under our experimental conditions. This may due to the introduction of imidazole ring in auxiliary ligands substituted with 1, 10-phenanthroline, which leads to formation of a richer conjugated armatic structure, thus resulting in stronger insertion into DNA. Meanwhile, the presence of an $-\mathrm{OH}$ group on the aromatic moieties, which acts as a electron-donating

\begin{tabular}{|c|c|}
\hline Compounds & $\mathbf{\Omega}^{-1} \mathbf{c m}^{\mathbf{2}} \mathbf{m o l}^{-\mathbf{1}}$ \\
\hline HPIP & 8.6 \\
\hline m-HHPIP & 9.8 \\
\hline p-HPIP & 11.4 \\
\hline VO(hntdtsc)(HPIP) & 13.6 \\
\hline VO(hntdtsc)(m-HPIP) & 12.8 \\
\hline VO(hntdtsc)(p-HPIP) & 18.1 \\
\hline
\end{tabular}

Table 1: Molar conductivity data of oxovanadium complexes and ligands. 

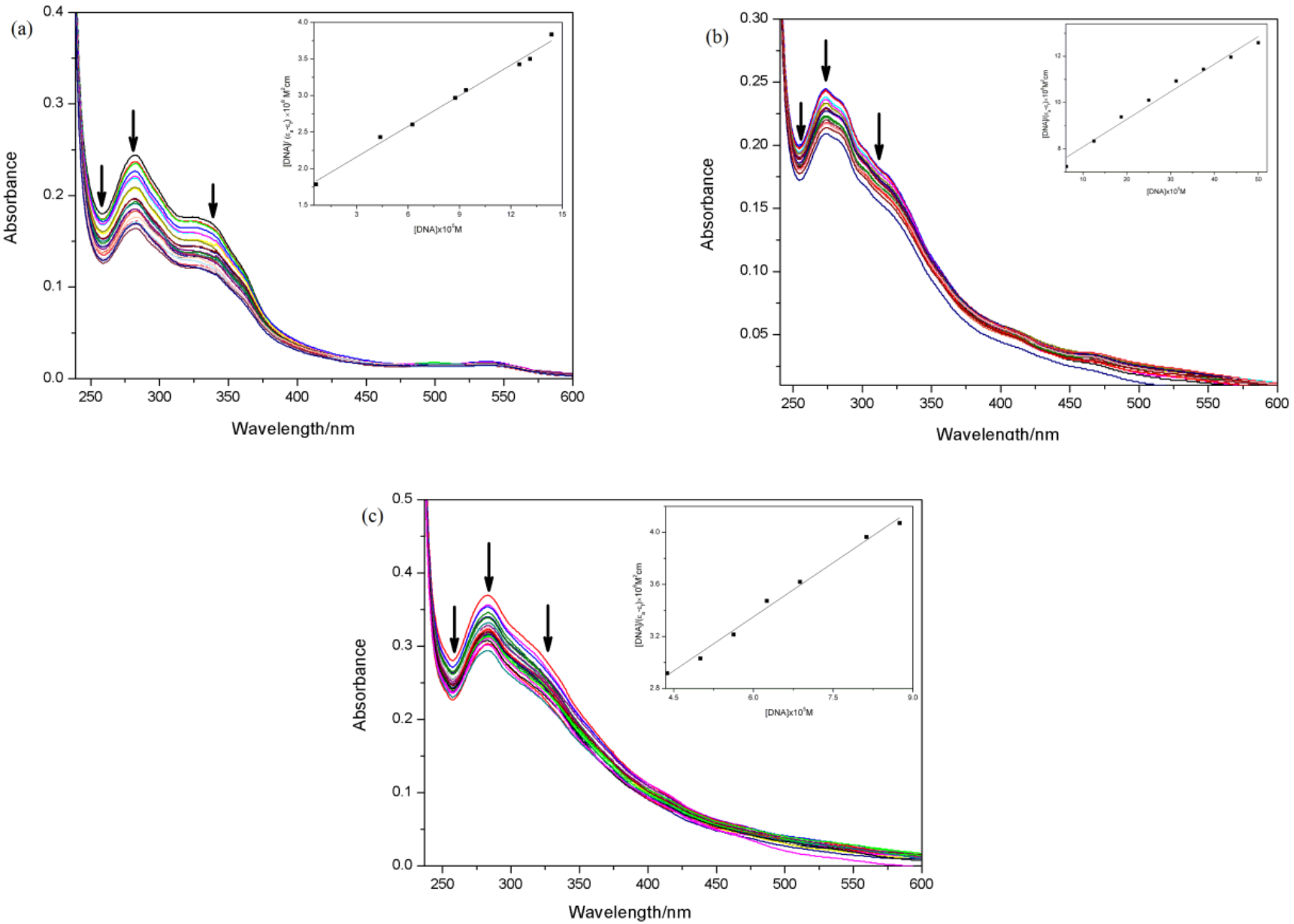

Figure 1: absorption spectral of the complexes 1 (a), 2 (b) and 3 (c) in Tris-HCl buffer A upon increasing amounts of CT-DNA. [V] $=20 \mu M,[D N A]=(0-100) \mu M$. Arrow shows the decreasing absorbance upon increasing CT-DNA concentrations. Insert: Plots of [DNA] $\left(\varepsilon_{a}-\varepsilon_{f}\right)$ versus [DNA] for the titration of [V] with CT-DNA.

substituent on the intercalative ligand and thus gives stronger stacking interactions with DNA.

The intrinsic binding constant, $K_{b}$ increase in the order $2<3<1$. Interestingly, from a comparison of the DNA-binding activities of complexes 1, 2 and 3, the complex 1 appeared to be a much stronger DNA intercalator. The differences of their binding strength may due to the changes in the electronic characteristics of substituted group at the different locations introduced on the aromatic ring of phenanthrolinebased ligands, which may make differences in the DNA-binding affinities. The results also indicates an $-\mathrm{OH}$ group substituted on the ortho-position of the aromatic ring exhibits stronger DNA-binding affinity than substituted on the para-position and meta-position $[19,28]$. And it thus provides strong evidence for the electronic effect of phenanthroline is one of the factors in determining the binding affinities.

\section{Fluorescence spectroscopic studies}

The interaction of the complexes $\left(20 \mu \mathrm{mol} \mathrm{L}^{-1}\right)$ with CT-DNA was investigated using fluorescence emission titration experiment in the Tris buffer A at room temperature. The emission spectra of complexes 1, 2 and 3 in the absence and presence of CT-DNA exhibit luminescence in Tris buffer A, with a maxima appearing at $296 \mathrm{~nm}, 656$ $\mathrm{nm}$ and $697 \mathrm{~nm}$ respectively, which are shown in Figure 2. Emission intensity of complexes 1-3 is found to depend on DNA concentration.
Upon increasing concentrations of CT-DNA, the emission intensities of complexes 1-3 grow to around by about $1.21,0.38$, and 0.64 times larger than those in the absence of CT-DNA and saturates at a [DNA]/[V] ratio of $20: 1$. The enhancement of emission intensity is an indication of binding of the complexes to the hydrophobic pocket of DNA, since the hydrophobic environment inside the DNA helix reduces the accessibility of water molecules to the complex and the complex mobility is restricted at the binding site, leading to decrease of the vibrational modes of relaxation [38]. The fluorescence spectroscopic data shows that 1 interacts with CT-DNA more strongly than both 1 and 2, consistent with the UV-Vis absorption titration spectral results.

\section{Viscosity measurements}

Viscosity measurements are regarded as the least controversial and the most rigorous means of testing the binding mode of DNA in solution $[19,28]$. To further clarify the DNA-binding mode of complexes 1-3, viscosity measurements on solutions of CT-DNA incubated with the complexes were performed. It is well-known that a classical intercalation model leads to an apparent increase in viscosity of DNA solution due to base-pairs are pushed apart and hence an increase in overall DNA length. In contrast, a partial, non-classical intercalation of compounds could bend (or kink) the DNA helix and reduce its effective length and, concomitantly, its viscosity [19,20,24].

The effects of complexes 1-3 on the viscosity of CT-DNA are shown 

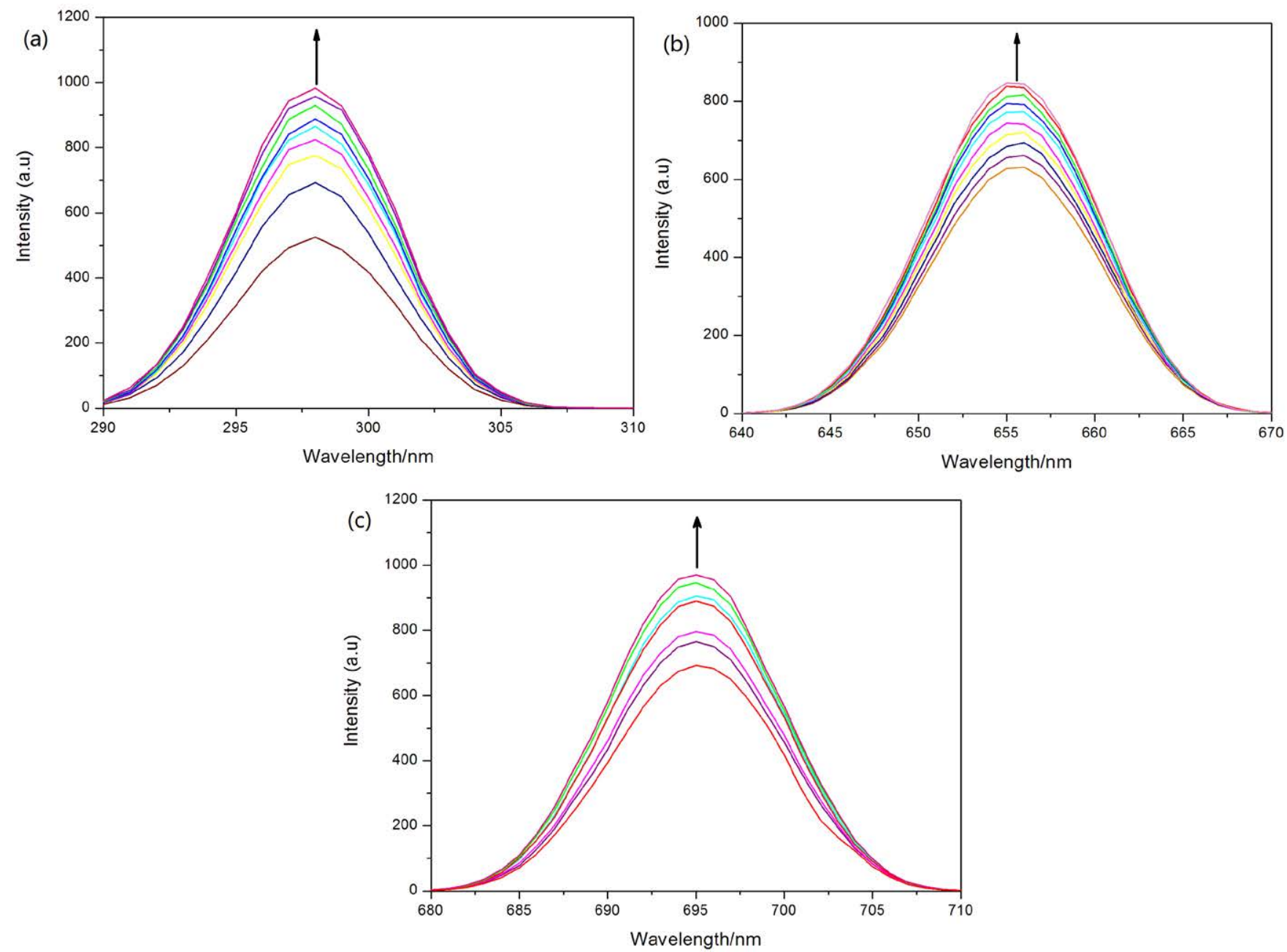

Figure 2: Emission spectra of 1 (a), 2 (b) and 3 (c) in Tris- $\mathrm{HCl}$ buffer $\mathrm{A}$ in the absence and presence of CT-DNA. [V] $=20 \mu \mathrm{mol} \mathrm{L}^{-1}$. Arrows show the increasing intensity with increasing concentrations of DNA.

in Figure 3. As can be seen in Figure 3, with amounts of the complexes increasing, the relative viscosity of DNA increases continuously to some extend. The results thus provide strong evidence for the interaction of complexes 1-3 with CT-DNA by intercalation modes. Moreover, the large increase in the relative viscosity revealed that 1 is a better intercalator than 2 and 3 , which is consistent with our foregoing hypothesis that electronic effects of introduction of larger planar aromatic rings on phenanthroline-based ligands play a key role in DNA-binding affinities.

\section{Thermal denaturation studies}

DNA melting experiments are generally applied to investigate the extent of intercalation, which were carried out by monitoring the intensity of DNA bases at $260 \mathrm{~nm}$ at different temperatures, both in the absence and presence of oxovanadium complex and ligands. Thermal behaviors of DNA in the presence of compounds can give insight into their conformational changes when the temperature is raised and offer information about the interaction strength of complexes with DNA. With the temperature in the solution rising, the doublestranded DNA will gradually dissociate to single strands and generate a hyperchromic effect on absorption spectra of DNA bases. Thus, the melting temperature $T_{m}$, which is defined as the temperature where half of the total base pairs are unbounded, is usually introduced. Generally,
$\mathrm{T}_{\mathrm{m}}$ will increase considerable when intercalative binding occurs, since intercalation of the complex into DNA base pairs causes stabilization of base stacking and hence raises the melting temperature of the doublestranded DNA $[13,24,28]$.

The melting curves of CT-DNA in the absence and presence of complexes 1, 2 and 3 are shown in Figure 4. As can be seen from Figure 4 , the $\mathrm{T}_{\mathrm{m}}$ of CT-DNA in the absence of the complex is $61.6 \pm 0.2^{\circ} \mathrm{C}$, meanwhile, when the complexes at a concentration ratio [V]/[DNA] of $1: 4$, we can observe that $T_{m}$ values in the presence of the complexes $1-3$ are $71.4 \pm 0.2^{\circ} \mathrm{C}, 64.7 \pm 0.2^{\circ} \mathrm{C}$ and $67.8 \pm 0.2^{\circ} \mathrm{C}$, respectively. A comparison of the $\Delta \mathrm{T}_{\mathrm{m}}$ values of the complex and its ligands $\left(9.8^{\circ} \mathrm{C}\right.$, $3.1^{\circ} \mathrm{C}$ and $6.2^{\circ} \mathrm{C}$, respectively) was agreement with those classical intercalators $[19,20,24,28]$, which provided strong evidence for their binding with DNA by intercalation modes.

The experimental data reveals that oxovanadium complexes in collaboration with Schiff base and imidazole[4,5-f][1,10] phenanthroline-based ligands exhibit appreciable DNA intercalative activities, it is quite consistent with their binding abilities with CTDNA.

\section{Photocleavage studies}

The interaction mode between the oxovanadium complex and 


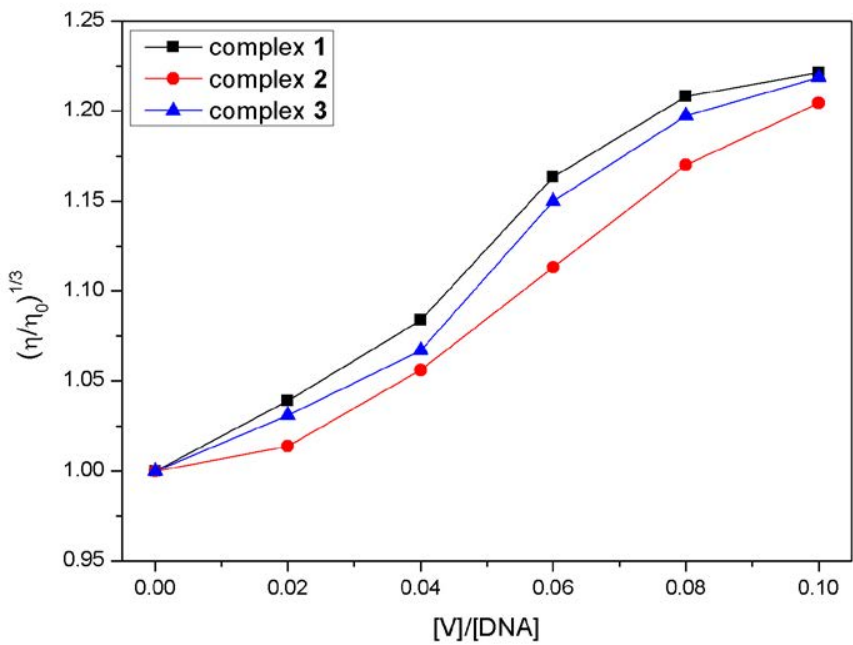

Figure 3: Effect of increasing amounts of complexes $1(\boldsymbol{\square}), 2(\bullet)$ and $3(\boldsymbol{\Delta})$ on the relative viscosity of CT-DNA at $(28.0 \pm 0.1)^{\circ} \mathrm{C}$, $[\mathrm{DNA}]=0.2 \mathrm{mmol} \mathrm{L}^{-1}$.

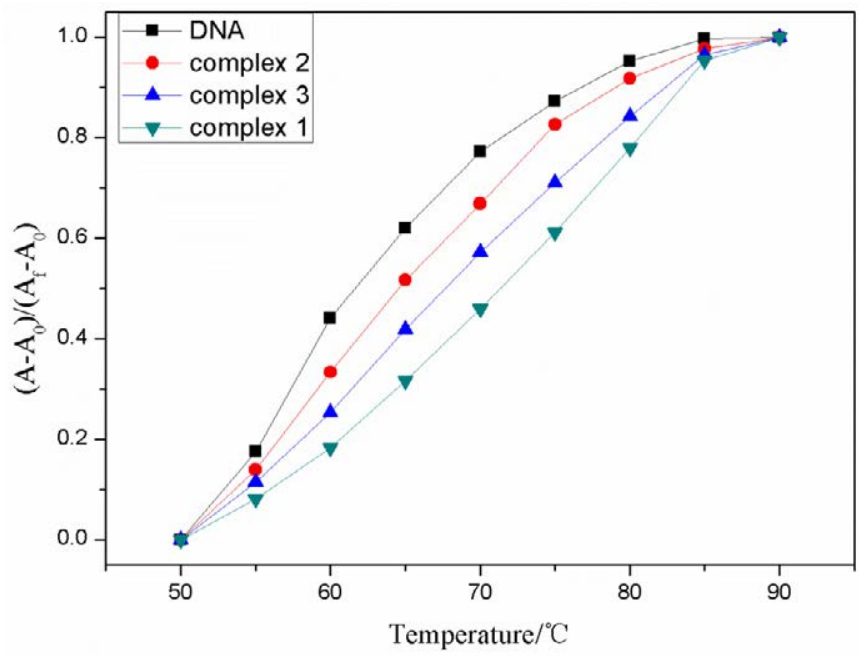

Figure 4: Thermal denaturation of CT-DNA in the absence and presence of complexes $1(\boldsymbol{\nabla}), 2(\bullet)$ and $3(\boldsymbol{\Delta}),[\mathrm{V}]=20 \mu \mathrm{M}$, [DNA] $=80 \mu \mathrm{M}$.

plasmid DNA was further investigated by agarose gel electrophoresis experiments. When circular plasmid DNA is subject to electrophoresis, relatively fast migration will be observed for the intact supercoiled form (form I). If scission occurs on one strand (nicking), the supercoil will relax to generate a slower moving open circular form (form II). If both strands are cleaved, a linear form (form III) will be generated [39]. The cleavage reactions on plasmid DNA induced by oxovanadium complexes were investigated and monitored by gel electrophoresis experiments.

As is shown both in Figure 5 and 6, it is clear to figure out the cleavage activity of plasmid pBR322 DNA after incubation with different concentrations of $\mathrm{V}$-complexes at $37^{\circ} \mathrm{C}$ for $1 \mathrm{~h}$ at dark condition. The nicked form II can barely observed for $\mathrm{H}_{2} \mathrm{O}_{2}$ alone in the absence of the complexes (lane 2 in Figures 5 and 6, respectively). Nevertheless, in the presence of complexes 1,2 and 3 with $30 \mathrm{mM} \mathrm{H}_{2} \mathrm{O}_{2}$, apparent cleavage of pBR322 DNA observed from the formation of form II, and cleaving activity tends to increase gradually with the concentration of the complexes increase from $15 \mu \mathrm{mol} \mathrm{L}^{-1}$ to $60 \mu \mathrm{M}$ (lane 3, 4 and 5 in Figures 5 and 6). Furthermore, under the same conditions with lane 4, addition of $0.02 \mathrm{~mol} \mathrm{~L}^{-1} \mathrm{~L}$-Histidine works as a singlet oxygen quencher (lane 6, lane 11 in Figures 5 and 6, respectively) slightly inhibits the cleavage of DNA. Meanwhile, no cleavage of plasmid DNA occurred in the presence of hydroxyl radical scavenger DMSO (lane 7, lane 12 in Figures 5 and 6 , respectively), suggesting that $\cdot \mathrm{OH}$ radicals is likely to be the reactive species on account of the oxidation of $\mathrm{VO}^{2+}$ in the presence of $\mathrm{H}_{2} \mathrm{O}_{2}$ for the cleavage reaction $[19,24,28]$. Under comparative experimental conditions, the cleavage ability follows the order of $1>3$ $>2$. The results are actually consistent with the degree of their intrinsic binding constant $\left(K_{b}\right)$, indicating that the introduction of imidazole ring on the auxiliary ligands substituted with 1,10-phenanthroline as well as electrochemical characteristics of the existence of substituted electronic-donating group (-OH) at the different locations introduced on the aromatic ring of phenanthroline-based ligands makes a big difference in the DNA-binding affinity.

\section{In vitro cytotoxicity assays}

The cytotoxicity in vitro assay for complexes 1-3 against cervical cancer CaSki and SiHa, leukemia K562, HepG2, esophagus carinoma EC9706 and EC109 cell lines were evaluated by MTT assay. The inhibititory percentage against growth of cancer cells was determined. The cell viabilities (\%) obtained with continuous exposure for 48 $\mathrm{h}$ are depicted in Figure 7 . Cell viability decreased with increasing concentrations of 1-3. The $\mathrm{IC}_{50}$ values were calculated and are listed in Table 2. As shown in Table 2, three oxovanadium complexes exhibit broad inhibition of tested cancer cell lines, with $\mathrm{IC}_{50}$ values ranging from 0.41 to $89.2 \mu \mathrm{M}$, and the cytotoxicity was concentrationdependent.

It is notable that complex 1 possessed the most potent cytotoxicity against the cell lines of CaSki, SiHa, K562, HepG2, EC9706 and EC109. Although complexes 2 and 3 appeared to be less antiproliferative activity towards HepG2, complex 1 still show high inhibitory effect, which $\mathrm{IC}_{50}$ values reaches to $0.73 \mu \mathrm{M}$. This is consistent with its binding abilities with CT-DNA, indicating that the antitumor abilities of the oxidovanadium complexes may be closely related to their DNA binding mode.

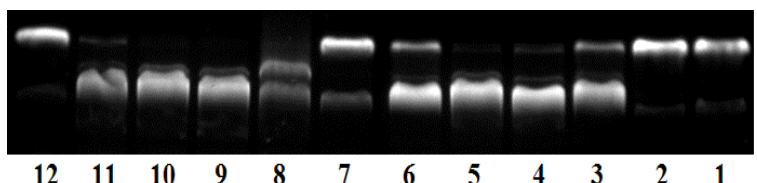

Form I

Form II

Figure 5: Cleavage of pBR322 DNA by complexes 2 and $3(15-60 \mu \mathrm{M})$ in the absence and presence of $\mathrm{H}_{2} \mathrm{O}_{2}(30 \mathrm{mM})$ in buffer $\mathrm{B}(\mathrm{pH}$ 7.2). lane 1, DNA control; lane 2, DNA + $\mathrm{H}_{2} \mathrm{O}_{2}$; lane 3, DNA + $2(15 \mu \mathrm{M})+\mathrm{H}_{2} \mathrm{O}_{2}$; lane 4, DNA + $2(30 \mu \mathrm{M})+\mathrm{H}_{2} \mathrm{O}_{2}$; lane 5, DNA + $2(60 \mu \mathrm{M})+\mathrm{H}_{2} \mathrm{O}_{2}$; lane 6, DNA + $2(30 \mu \mathrm{M})$ $+\mathrm{H}_{2} \mathrm{O}_{2}+$ L-Histidine (0.02 M); lane 7, DNA + $2(30 \mu \mathrm{M})+\mathrm{H}_{2} \mathrm{O}_{2}+$ DMSO $(2 \mu \mathrm{L})$; lane 8, DNA + $3(15 \mu \mathrm{M})+\mathrm{H}_{2} \mathrm{O}_{2}$; lane 9, DNA + $3(30 \mu \mathrm{M})+\mathrm{H}_{2} \mathrm{O}_{2}$; lane 10 $\mathrm{DNA}+3(60 \mu \mathrm{M})+\mathrm{H}_{2} \mathrm{O}_{2}$; lane 11 , DNA + $3(30 \mu \mathrm{M})+\mathrm{H}_{2} \mathrm{O}_{2}+$ L-Histidine $(0.02$ $\mathrm{M})$; lane 12, DNA $+3(30 \mu \mathrm{M})+\mathrm{H}_{2} \mathrm{O}_{2}+$ DMSO $(2 \mu \mathrm{L})$.

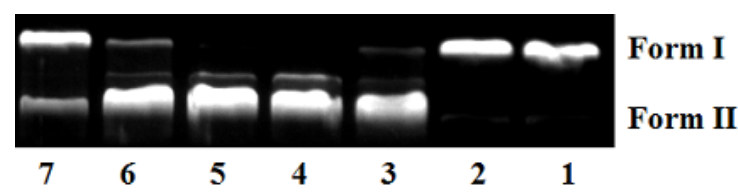

Figure 6: Cleavage of pBR322 DNA by complex $1(15-60 \mu \mathrm{M})$ in the absence and presence of $\mathrm{H}_{2} \mathrm{O}_{2}(30 \mathrm{mM})$ in buffer $\mathrm{B}(\mathrm{pH} 7.2)$. lane 1, DNA control; lane 2, DNA + $\mathrm{H}_{2} \mathrm{O}_{2}$; lane 3, DNA + $1(15 \mu \mathrm{M})+\mathrm{H}_{2} \mathrm{O}_{2}$; lane 4, DNA + $1(30 \mu \mathrm{M})$ $+\mathrm{H}_{2} \mathrm{O}_{2}$; lane 5, DNA + $1(60 \mu \mathrm{M})+\mathrm{H}_{2} \mathrm{O}_{2}$; lane 6, DNA + $1(30 \mu \mathrm{M})+\mathrm{H}_{2} \mathrm{O}_{2}+$ L-Histidine (0.02 M); lane 7, DNA + $1(30 \mu \mathrm{M})+\mathrm{H}_{2} \mathrm{O}_{2}+$ DMSO $(2 \mu \mathrm{L})$. 

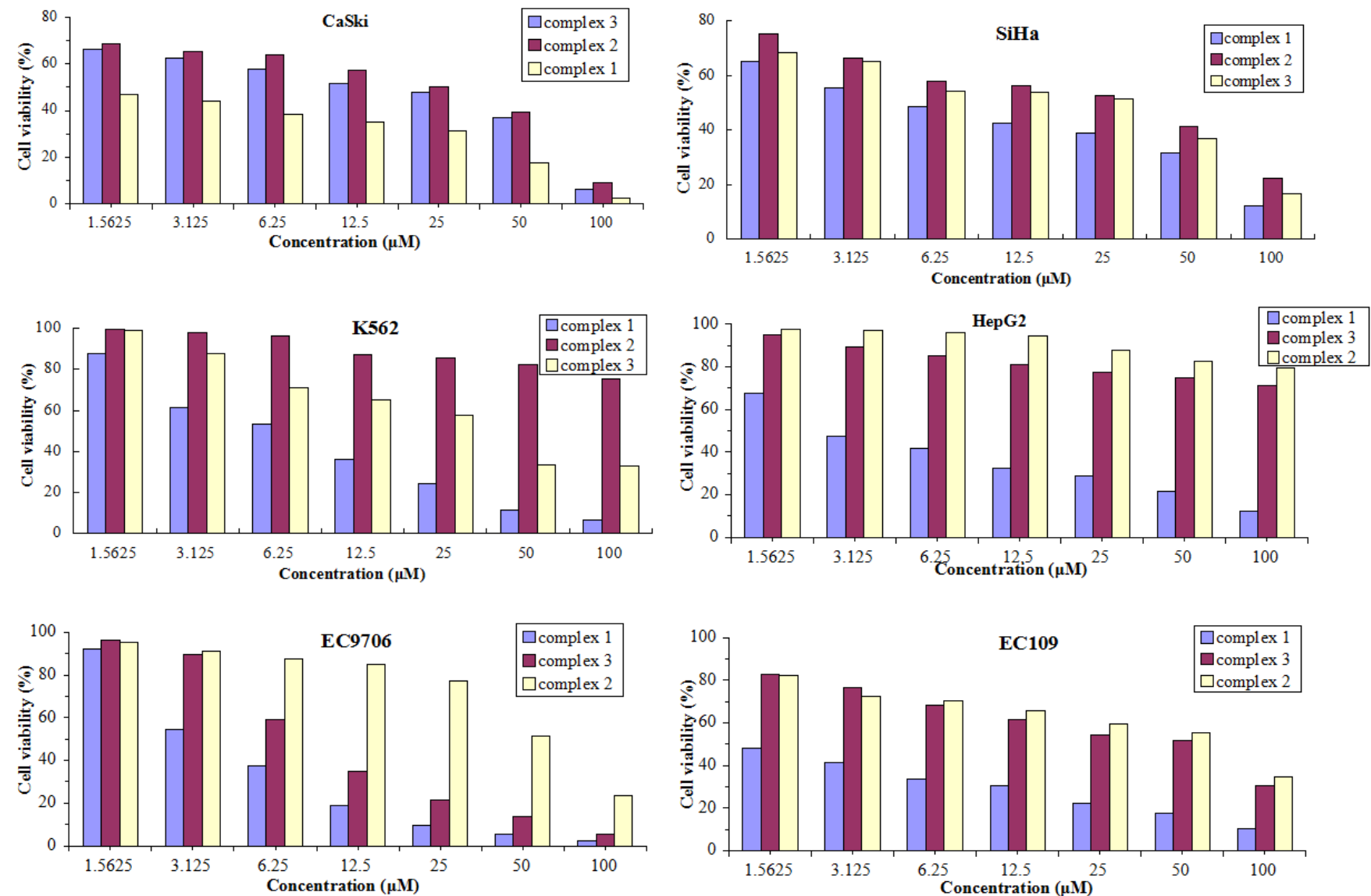

Figure 7: Cell viability of 1, 2 and 3 on tumor CaSki, SiHa, K562, HepG2, EC9706 and EC109 cell proliferation in vitro. Each data point is the mean \pm standard error obtained from at least three independent experiments.

\begin{tabular}{|c|c|c|c|c|c|}
\hline Compounds & \multicolumn{4}{|c|}{ IC $_{50}(\mu \mathrm{M})$} \\
\hline & CaSki & SiHa & K562 & Hep G2 & EC9706 \\
\hline Complex 1 & $0.69 \pm 0.1$ & $5.5 \pm 0.4$ & $3.6 \pm 0.2$ & $0.73 \pm 0.2$ & $4.7 \pm 0.8$ \\
\hline Complex 2 & $11.2 \pm 1.1$ & $10.2 \pm 1.3$ & $51.9 \pm 2.6$ & $0.41 \pm 0.1$ & $>100$ \\
\hline Complex 3 & $22.8 \pm 1.4$ & $20.7 \pm 1.7$ & $>100$ & $22.8 \pm 1.8$ & $>100$ \\
\hline
\end{tabular}

Table 2: The $\mathrm{IC}_{50}$ values for $\mathbf{1}, \mathbf{2}$ and $\mathbf{3}$ against selected cell lines.

\section{Conclusion}

In this paper, three oxovanadium complexes incorporating Schiff base and phenanthroline-based ligands have been synthesized and characterized. Their DNA-binding activities with CT-DNA indicate that they bind to DNA by intercalation modes and the DNA-binding affinity follows the order $1>3>2$. These oxovanadium complexes can cause DNA cleavage. The results imply that the interaction with DNA may be closed associated with the introduction of imidazole ring in auxiliary ligands substituted with 1,10-phenanthroline as well as the electronic effects of substituted electronic-donating group $(-\mathrm{OH})$ at the different locations introduced on the aromatic ring of phenanthrolinebased ligands makes a big difference in the DNA-binding affinity. Furthermore, they also show highly cytotoxic activities against cervical, leukemia, Hepatoma and esophagus carcinoma cell lines. Complex 1 was found to be the most potent antitumor agent among the three complexes. Further investigation is required to study the possible cytotoxicity mechanisms of these complexes.

\section{Acknowledgements}

We gratefully acknowledge financial support for this work by the Science and technology Research Project of Guangdong Province (No.2012B031800431), P. R China and Cultivation of Natural Science Joint Fund of the First Affiliated Hospital and the Scientific \& Technical Department of Guangdong Pharmaceutical University (No. 2014-36).

\section{References}

1. Srishaliam A, Kumar YP, Venkat Reddy $P$, Nambigari N, Vuruputuri U, et al (2014) Cellular uptake, cytotoxicity, apoptosis, DNA-binding, photocleavage and molecular docking studies of ruthenium(II) polypyridyl complexes. J Photochem Photobiol B 132: 111-123.

2. Liu ML, Jiang M, Zheng K, Li YT, Wu ZY, et al. (2014) Synthesis and structure of a new mononuclear copper(II) complex with 2,2'-bipyridine and picrate: molecular docking, DNA-binding, and in vitro anticancer activity. J Coord Chem 67: $630-648$

3. Basu Baul TS, Kundu S, Linden A, Raviprakash N, Manna SK, et al. (2014) Synthesis and characterization of some water soluble $\mathrm{Zn}$ (II) complexes with (E)-N-(pyridin-2-ylmethylene)arylamines that regulate tumour cell death by interacting with DNA. Dalton Trans 43: 1191-1202.

4. Guin PS, Mandal PC, Das S (2012) A comparative study on the interaction with calf thymus DNA of a Ni(II) complex of the anticancer drug adriamycin and a $\mathrm{Ni}(\mathrm{II})$ complex of sodium 1,4-dihydroxy-9,10-anthraquinone-2-sulphonate. J Coord Chem 65: 705-721.

5. Wang QX, Gao F, Gao F, Li SX, Weng W, et al. (2012) A novel hybridization 
Citation: Ying P, Tian X, Zeng P, Lu J, Chen H, et al. (2014) Synthesis, DNA-binding, Photocleavage and in vitro Cytotoxicity of Novel Imidazole[4,5-f] $[1,10]$ phenanthroline-based Oxovanadium Complexes. Med chem 4: 549-557. doi:10.4172/2161-0444.1000193

indicator for the low-background detection of short DNA fragments based on an electrically neutral cobalt(II) complex. Biosens Bioelectron 32: 50-55.

6. Nielsen FH (1998) The nutritional essentiality and physiological metabolism of vanadium in higher animals. ACS Symp Ser 711: 297-307.

7. Morsy MD, Abdel-Razek HA, Osman OM (2011) Effect of vanadium on renal $\mathrm{Na}+, \mathrm{K}+-\mathrm{ATPase}$ activity in diabetic rats: a possible role of leptin. J Physio Biochem 67: 61-69.

8. Zwolak I (2014) Vanadium carcinogenic, immunotoxic and neurotoxic effects: a review of in vitro studies. Toxicol Mech Methods 24: 1-12.

9. Anupama B, Gyana KC (2011) Synthesis, characterization, DNA binding and antimicrobial activity of 4 -amino antipyrine Schiff base metal complexes. Res $J$ Pharm Biol Chem Sci 2: 140-159.

10. Walmsley RS, Litwinsk C, Antunes E, Hlangothi P, Hosten E, et al. (2013) Oxovanadium(IV)-containing poly(styrene-co-4'-ethenyl-2-hydroxyphenylimidazole) electrospun nanofibers for the catalytic oxidation of thioanisole. J Mol Catal A: Chem 379: 94-102.

11. Sanna D, Micera G, Garribba E (2013) Interaction of insulin-enhancing vanadium compounds with human serum holo-transferrin. Inorg Chem 52 : $11975-11985$.

12. Yamaguchi T, Watanabe S, Matsumura Y, Tokuoka Y, Yokoyama A (2012) Oxovanadium complexes with quinoline and pyridinone ligands: syntheses of the complexes and effect of alkyl chains on their apoptosis-inducing activity in leukemia cells. Bioorg Med Chem 20: 3058-3064.

13. Liao X, Pan W, He R, Guo H, Ying P, et al. (2014) Unsymmetrical oxovanadium complexes derived from salicylaldehyde and phenanthroline: synthesis, DNA interactions, and antitumor activities. Chem Biol Drug Des 83: 367-378.

14. Khatun R, Islam ASMA, Hai MA (2012) Synthesis of Schiff base having a heterocyclic moiety along with its cyclized derivatives and study of their antifungal activities. J Bangladesh Chem Soc 25: 7-14

15. Ali AQ, Teoh SG, Salhin A, Eltayeb NE, Khadeer Ahamed MB, et al. (2014) Synthesis of isatin thiosemicarbazones derivatives: in vitro anti-cancer, DNA binding and cleavage activities. Spectrochim Acta A Mol Biomol Spectrosc 125 $440-448$

16. Rai BK, Kumari R (2013) Synthesis, structural, spectroscopic and antibacterial studies of Schiff base ligands and their metal complexes containing nitrogen and sulphur donor atom. Orient J Chem 29: 1163-1167.

17. Abbas SY, Farag AA, Ammar YA, Atrees AA, Mohamed AF, et al. (2013) Synthesis, characterization, and antiviral activity of novel fluorinated isatin derivatives. Monatsh Chem 144: 1725-1733.

18. Maia PIDS, Pavan FR, Leite CQF, Lemos SS, de Sousa GF, et al. (2009) Vanadium complexes with thiosemicarbazones: Synthesis, characterization, crystal structures and anti-Mycobacterium tuberculosis activity. Polyhedron 28 : 398-406.

19. Guo HW, Lu JZ, Ruan ZG, Zhang YL, Liu YJ, et al. (2012) Synthesis, DNAbinding, cytotoxicity, and cleavage studies of unsymmetrical oxovanadium complexes. J Coord Chem 65: 191-204.

20. Lu JZ, Du YF, Guo HW, Jiang J, Zeng XD, et al. (2011) Two oxovanadium complexes incorporating thiosemicarbazones: synthesis, characterization, and DNA-binding studies. J Coord Chem 64: 1229-1239.

21. Jin, XP, Zhang L, Gao HQ, Fang JH, Li RF, et al. (2013) Palladium- and coppercatalyzed cross coupling reaction of aliphatic alcohols and aryl halides. Huaxue Jinzhan 25: 1898-1905

22. Martinez Medina JJ, Islas MS, Lopez Tevez LL, Ferrer EG, Okulik NB, et al. (2014) Copper(II) complexes with cyanoguanidine and o-phenanthroline: Theoretical studies, in vitro antimicrobial activity and alkaline phosphatase inhibitory effect. J Mol Struct 1058: 298-307.

23. Anbu S, Killivalavan S, Alegria ECBA, Mathan G, Kandaswamy M (2013) Effect of 1,10-phenanthroline on DNA binding, DNA cleavage, cytotoxic and lactate dehydrogenase inhibition properties of Robson type macrocyclic dicopper(II) complex. J Coord Chem 66: 3989-4003.

24. Liu YJ, Li ZZ, Liang ZH, Yao JH, Huang HL (2011) Cytotoxicity, apoptosis cellular uptake, cell cycle arrest, photocleavage, and antioxidant activity of 1 10-phenanthroline ruthenium(II) complexes. DNA Cell Biol 30: 839-848.

25. Kalia SB, Kaushal G, Kumar M, Cameotra SS, Sharma A, et al. (2009) Antimicrobial and toxicological studies of some metal complexes of 4-methylpiperazine-1-carbodithioate and phenanthroline mixed ligands. Braz J Microbiol 40: 916-922.

26. Bonello RO, Morgan IR, Yeo BR, Jones LEJ, Kariuki BM, et al. (2014) Luminescent rhenium(I) complexes of substituted imidazole[4,5-f]-1,10phenanthroline derivatives. Journal of Organometallic Chemistry 749: 150-156.

27. Gomleksiz M, Alkan C, Erdem B (2013) Synthesis, characterization and antibacterial activity of imidazole derivatives of 1,10-phenanthroline and their $\mathrm{Cu}(\mathrm{II}), \mathrm{Co}(\mathrm{II})$ and $\mathrm{Ni}(\mathrm{II})$ complexes. S Afr J Chem 66: 107-112.

28. Lu J1, Guo H, Zeng X, Zhang Y, Zhao P, et al. (2012) Synthesis and characterization of unsymmetrical oxidovanadium complexes: DNA-binding, cleavage studies and antitumor activities. J Inorg Biochem 112: 39-48.

29. Cai ZB, Liu LF, Hong YQ, Zhou M (2013) Synthesis, characterization, and nonlinear optical responses of nickel(II) complexes with phenanthroline-based ligands. J Coord Chem 66: 2388-2397.

30. Tabatabaee $M$, Bordbar $M$, Ghassemzadeh $M$, Tahriri $M$, Tahriri $M$, et al. (2013) Two new neutral copper(II) complexes with dipicolinic acid and 3-amino$1 \mathrm{H}-12,4$-triazole formed under different reaction conditions: Synthesis, characterization, molecular structures and DNA-binding studies. Eur J Med Chem 70: 364-371.

31. Hazari PP1, Pandey AK, Chaturvedi S, Tiwari AK, Chandna S, et al. (2012) Synthesis of oxovanadium(IV) Schiff base complexes derived from C-substituted diamines and pyridoxal-5-phosphate as antitumor agents. Chem Biol Drug Des 79: 223-234.

32. Masango MG, Ferreira GC, Ellis CE, Elgorashi EE, Botha CJ (2014) Cytotoxicity of diplodiatoxin, dipmatol and diplonine, metabolites synthesized by Stenocarpella maydis. Toxicon 82: $26-29$.

33. Jabeen M, Ali S, Shahzadi S, Sharma SK, Qanungo K (2014) Synthesis, characterization, theoretical study and biological activities of oxovanadium (IV) complexes with 2-thiophene carboxylic acid hydrazide. J Photochem Photobio B 136: 34-45.

34. Chen C, Bai FY, Zhang R, Song G, Shan H, et al. (2013) Synthesis, structure, and catalytic bromination of supramolecular oxovanadium complexes containing oxalate. J Coord Chem 66: 671-688.

35. Nejo AA, Kolawole GA, Opoku AR, Wolowska J, Brien PO (2009) Synthesis, characterization and preliminary insulin-enhancing studies of symmetrical tetradentate Schiff base complexes of oxovanadium(IV). Inorganica Chimica Acta 362: 3993-4001.

36. Yang PJ, Cui FJ, Yang XJ, Wu B (2013) Syntheses and Structures of Mononuclear, Dinuclear and Polynuclear Silver(I) Complexes of 2-PyrazoleSubstituted 1,10-Phenanthroline Ligands. Cryst Growth Des 13: 186-194.

37. Chen C, Bai FY, Zhang R, Song G, Shan H, et al. (2013) Synthesis, structure, and catalytic bromination of supramolecular oxovanadium complexes containing oxalate. J Coord Chem 66: 671-688.

38. Liang XL, Tan LF, Zhu WG (2011) Study on DNA-binding and DNA-cleavage properties of $\mathrm{Cr}(\mathrm{III})$ complexes with polypyridyl ligands. DNA Cell Biol 30: 61 67.

39. Li H, Bo H, Wang J, Shao H, Huang S (2011) Separation of supercoiled from open circular forms of plasmid DNA, and biological activity detection. Cytotechnology 63: 7-12. 